\title{
Accuracy of mobility tests for screening the risk of falls in patients with mild cognitive impairment and alzheimer's disease
}

\author{
Acurácia de testes de mobilidade para o rastreio do risco de quedas no comprometimento \\ cognitivo leve e doença de Alzheimer
}

Exactitud de las pruebas de movilidad para detectar riesgo de caídas en el deterioro cognitivo leve y en la enfermedad de Alzheimer

\author{
Juliana Hotta Ansai', Verena Vassimon-Barroso², Ana Claudia Silva Farche ${ }^{3}$, \\ Marcele Stephanie de Souza Buto ${ }^{4}$, Larissa Pires de Andrade ${ }^{5}$, José Rubens Rebelatto ${ }^{6}$
}

\begin{abstract}
Identifying gait and balance disorders in the earlier stages of Alzheimer's disease (AD) and Mild Cognitive Impairment $(\mathrm{MCl})$ could reduce or prevent falls in older adults. This cross-sectional study aimed to determine which mobility tests best discriminate the risk of falls in $\mathrm{MCl}$ and mild $\mathrm{AD}$. Functional mobility was assessed by the timed up and go test (TUG) and 10-meter walk test (10MWT). A calendar of falls was produced, with follow-up via telephone calls during 6 months. For the MCl Group ( $\mathrm{n}=38$ ), time spent on the 10MWT was the best variable for discriminating fallers, with a cut-off point of 10.69 seconds associated with the highest accuracy (76.3\%). In the AD Group ( $n=37$ ), 10MWT cadence was the best variable for discriminating fallers, with a cut-off point of 101.39 steps per minute associated with an accuracy of $81.1 \%$. As a conclusion, 10MWT time and cadence were the most accurate variables for screening the risk of falls in $\mathrm{MCl}$ and mild AD, respectively. The 10MWT is a functional, simple and easy test and it should be widely used in clinical practice.
\end{abstract}

Keywords | Falls; Cognition; Aged.

RESUMO | A identificação de distúrbios da marcha e do equilíbrio em estágios iniciais da doença de Alzheimer (DA) e do comprometimento cognitivo leve (CCL) pode reduzir ou prevenir quedas na população idosa. Transversal, este estudo tem como objetivo determinar quais testes de mobilidade melhor discriminam o risco de quedas em idosos com CCL e DA leve. A mobilidade funcional foi avaliada pelo timed up and go test (TUG) e o teste de velocidade de marcha de 10 metros (10MWT). Foi produzido um calendário de quedas, com acompanhamento via contato telefônico durante 6 meses. Para o grupo CCL ( $n=38$ ), o tempo gasto no 10MWT foi a melhor variável para discriminar caidores, com nota de corte de 10,69 segundos associada a maior precisão (76,3\%). No grupo DA ( $n=37)$, a cadência do 10MWT foi a melhor variável para discriminar os caidores, com nota de corte de 101,39 passos por minuto associada a uma precisão de 81,1\%. Como conclusão, o tempo e a cadência do 10MWT foram as variáveis mais precisas para rastrear o risco de quedas em idosos com CCL e DA leve, respectivamente. O 10MWT é um teste funcional, simples e fácil e pode ser amplamente utilizado na prática clínica.

Descritores | Quedas; Cognição; Idosos.

RESUMEN | La identificación de los trastornos de marcha y del equilibrio en las primeras etapas de la enfermedad

Study conducted at the Department of Physical Therapy of Universidade Federal de São Carlos (UFSCar), São Carlos (SP), Brazil. ${ }^{1}$ Programa de Pós-Graduação em Ciências do Movimento, Universidade Federal de Mato Grosso do Sul (UFMS) - Campo Grande (MS), Brazil. E-mail: julianaansai@gmail.com. Orcid: 0000-0001-9873-3509

2Universidade Federal de São Carlos (UFSCar) - São Carlos (SP), Brazil. E-mail: verena.vassimon@gmail.com. Orcid: 0000-0001-8322-4023 3Universidade Federal de São Carlos (UFSCar) - São Carlos (SP), Brazil. E-mail: anaclaudiafarche@gmail.com. Orcid: 0000-0002-9502-1351 ${ }^{4}$ Universidade Federal de São Carlos (UFSCar) - São Carlos (SP), Brazil. E-mail: marcele.buto@gmail.com. Orcid: 0000-0003-0732-0755 5Universidade Federal de São Carlos (UFSCar) - São Carlos (SP), Brazil. E-mail: larissa.andrade@ufscar.br. Orcid: 0000-0002-8860-5818 6Universidade Federal de São Carlos (UFSCar) - São Carlos (SP), Brazil. E-mail: rubens@ufscar.br. Orcid: 0000-0002-5337-8256 
de Alzheimer (EA) y del deterioro cognitivo leve (DCL) puede reducir o prevenir las caídas en la población anciana. Estudio transversal que tiene como objetivo determinar qué pruebas de movilidad discriminan mejor el riesgo de caídas en los ancianos con DCL y EA leve. La movilidad funcional se evaluó mediante el timed up and go test (TUG) y la prueba de velocidad de marcha de 10 metros (10MWT). Se elaboró un calendario de caídas, con seguimiento vía contacto telefónico durante 6 meses. En el grupo DCL ( $n=38$ ), el tiempo empleado en el 10MWT fue la mejor variable para discriminar las caídas, con un puntaje de corte de 10,69 segundos asociado a una mayor precisión (76,3\%). En el grupo de EA ( $n=37)$, la cadencia de 10MWT fue la mejor variable para discriminar las caídas, con un puntaje de corte de 101,39 pasos por minuto asociada a una precisión del 81,1\%. Se concluye que el tiempo y la cadencia de 10MWT fueron las variables más precisas para detectar el riesgo de caídas en los ancianos con DCL y EA leve, respectivamente. El 10MWT es una prueba funcional, simple y fácil, y se puede utilizarla ampliamente en la práctica clínica.

Palabras clave | Caídas; Cognición; Anciano.

\section{INTRODUCTION}

Older people with cognitive impairment, such as mild cognitive impairment (MCI) and Alzheimer's disease (AD), are at increased risk of falls, with prevalence of falls up to $60 \%{ }^{1}$. In this sense, fall assessment and strategies for reducing or preventing falls are essential to avoid adverse outcomes, such as fractures, injuries and functional damage ${ }^{2}$. Falls are a serious public health problem, thus, earlier identification of potential fallers in this population is needed.

Gait and balance disorders may be identified even in earlier stages of $\mathrm{AD}$ and $\mathrm{MCI}^{3,4}$. These impairments have been reported as important contributors to the increased risk of falls in older adults with cognitive impairment ${ }^{5}$. The updated American/British Geriatrics Society guidelines for prevention of falls recommend that gait and balance deficits should be assessed in older individuals reporting a single fall and used as a screen for identifying individuals who may benefit from a multifactorial risk of fall assessment ${ }^{6}$.

Among several functional mobility tools, walk tests and the timed up and go test (TUG) are widely used in clinical practice. The 10-meter walk test (10MWT) has been used as an important predictor of functional capacity ${ }^{7}$ and as a predictor of multiple falls in community-dwelling older people, using a cut-off point around 6 seconds ${ }^{8}$. On the other hand, the TUG test is fast and easy to apply, and it was validated for screening risk of falls, with a cut-off point around 12 seconds in Brazilian older community people 9

Differences in mobility performance were found between fallers and non-fallers with cognitive impairment ${ }^{5}$, however, the separate analysis of people with $\mathrm{MCI}$ and $\mathrm{AD}$ in mild phase remains scarce. Knowing that prevalence and history of falls differ according to the cognitive impairment, type and phase of dementia ${ }^{10,11}$, analyzing the accuracy of functional mobility tests for screening risk of falls among MCI and mild AD is necessary to improve screening and prevention of falls in these populations. Therefore, the purpose of this study was to determine which of the two commonly used functional mobility tools (TUG and 10MWT) best discriminated risk of falls in Brazilian older community people with MCI and mild AD.

\section{METHODOLOGY}

\section{Participants}

Recruitment and prospective data collection were conducted between 2015 and 2016. Inclusion criteria were the ability to walk at least 10 meters alone without a walking aid and the availability to participate in the proposed assessments. Exclusion criteria were the presence of motor alterations after a stroke, other types of dementia, neurological disorders that interfered in cognition or mobility, severe uncorrected visual or auditory disorders and advanced or moderate $\mathrm{AD}$. An experienced neurologist professor confirmed the diagnosis of $\mathrm{MCI}$ and $\mathrm{AD}$ (mild stage) and the details of diagnosis criteria have been described in a previous study ${ }^{12}$.

\section{Procedures}

After written informed consent was obtained and before the assessments, the volunteers were instructed to wear comfortable clothing and closed usual shoes, to have eaten at least one hour prior to the assessments, to have avoided vigorous exercise the day before and to bring visual or auditory aids, if necessary. All assessments were conducted by the same two trained physical therapists in a closed environment. 
A structured questionnaire was administered and the following socio-demographic and clinical data were collected: age, sex, body mass index, educational level, number of comorbidities, use of psychotropic drugs, previous falls in the last year and level of physical activity (Minnesota Questionnaire) (kcal/week) ${ }^{13}$. The answers of the volunteers with $\mathrm{MCI}$ were confirmed by an informant, i.e., a person who stayed with the older adult at least half a day, four times per week. Both the volunteer with $\mathrm{AD}$ and his informant answered the questionnaire.

\section{Functional mobility}

Functional mobility was determined by the 10MWT and the TUG test. During the 10MWT, the volunteers were instructed to begin walking $1.2 \mathrm{~m}$ before the beginning of the course and to finish $1.2 \mathrm{~m}$ after the end of the course at usual speed in order to eliminate acceleration and deceleration components ${ }^{14}$. The test was conducted once, and time, number of steps and cadence were recorded for further analysis.

During the TUG test, the individual was instructed to stand up from a seated position (in a chair $45-\mathrm{cm}$ high with trunk support and armrests), walk $3 \mathrm{~m}$, turn around, walk back to the chair and sit down ${ }^{15}$. The TUG test was performed two times (1 familiarization and 1 test trial). Specific paused instructions of the test have been described in a previous study ${ }^{12}$. Time, number of steps and cadence were marked. Both mobility tests were performed without a walking aid.

\section{Falls follow-up}

Participants were followed up for six months. Each volunteer or informant received a calendar of falls and monthly telephone calls in order to ensure accurate data collection. The definition of fall was "an event which results in a person coming to rest inadvertently on the ground or floor or other lower level and other than as a consequence of the following: sustaining a violent blow; loss of consciousness; sudden onset of paralysis; or an epileptic seizure"16. Each group (MCI and AD) was subdivided in faller and non-faller. A faller was considered a person who fell at least once during the follow-up.

\section{Statistical analysis}

A significance level of 5\% was adopted and the SPSS software (20.0) was used. Data normality was tested by the Kolmogorov-Smirnov test. The Student's t-test and the Chi-square test were used to compare quantitative and categorical data between fallers and non-fallers in each group (MCI and $\mathrm{AD}$ ). Receiver operating characteristic (ROC) curves were used to determine the cut-off score that maximized sensitivity and specificity for each mobility test. Sensitivity describes the proportion of fallers who were correctly identified by the test as having risk of fall. Specificity describes the proportion of non-fallers who were correctly identified by the test as not having risk of fall. Accuracy was calculated as the total number of true positives and negatives divided by the total number of true and false positives and negatives ${ }^{17}$.

\section{RESULTS}

At baseline, 40 older people with MCI and 38 with mild $\mathrm{AD}$ were assessed. However, two women with $\mathrm{MCI}$ and one woman with $\mathrm{AD}$ died during follow-up and therefore their data were not analyzed. The prospective analysis was based on the performance of 38 people with MCI (20 fallers and 18 non-fallers) and 37 people with mild AD (19 fallers and 18 non-fallers). There were no differences at baseline between fallers and non-fallers of both MCI and AD groups, except in previous fall data. In the MCI Group, the faller subgroup showed more prevalence of previous falls (80\%) than the non-faller one $(\mathrm{p}<0.01)($ Table 1$)$.

Table 1. Baseline characteristics between fallers and non-fallers identified over the 6-month follow-up

\begin{tabular}{|c|c|c|c|c|c|c|}
\hline \multirow{3}{*}{ Characteristics, M (SD) } & \multicolumn{2}{|c|}{$\mathrm{MCl}$ Group } & \multirow{3}{*}{ P-value } & \multicolumn{2}{|c|}{ AD Group } & \multirow{3}{*}{ P-value } \\
\hline & Fallers & Non-fallers & & Fallers & Non-fallers & \\
\hline & $(n=20)$ & $(n=18)$ & & $(n=19)$ & $(n=18)$ & \\
\hline Age (years) & $77.3(6.2)$ & $74.1(6.5)$ & 0.140 & $78.1(6.1)$ & $77.0(6.2)$ & 0.592 \\
\hline Female sex, $n(\%)$ & $16(80.0)$ & $16(88.9)$ & 0.453 & $10(52.6)$ & $11(61.1)$ & 0.603 \\
\hline Body mass index $\left(\mathrm{kg} / \mathrm{m}^{2}\right)$ & $28.6(3.9)$ & $30.6(4.4)$ & 0.155 & $27.6(5.5)$ & $27.2(5.4)$ & 0.828 \\
\hline Educational level (years) & $4.5(4.3)$ & $5.7(3.6)$ & 0.337 & $5.8(4.5)$ & $5.2(4.8)$ & 0.715 \\
\hline Number of comorbidities & $2.5(1.2)$ & $3.3(1.5)$ & 0.083 & $3.1(1.3)$ & $3.6(1.0)$ & 0.190 \\
\hline
\end{tabular}


Table 1. Continuation

\begin{tabular}{|c|c|c|c|c|c|c|}
\hline \multirow{3}{*}{ Characteristics, M (SD) } & \multicolumn{2}{|c|}{$\mathrm{MCl}$ Group } & \multirow{3}{*}{ P-value } & \multicolumn{2}{|c|}{ AD Group } & \multirow{3}{*}{ P-value } \\
\hline & Fallers & Non-fallers & & Fallers & Non-fallers & \\
\hline & $(n=20)$ & $(n=18)$ & & $(n=19)$ & $(n=18)$ & \\
\hline Number of medication use & $5.1(2.8)$ & $5.2(3.8)$ & 0.912 & $5.9(4.1)$ & 4.5 (1.9) & 0.207 \\
\hline Psychotropic use, n (\%) & $8(40.0)$ & $6(33.3)$ & 0.671 & $17(89.5)$ & $12(66.7)$ & 0.092 \\
\hline Previous falls, n (\%) & $16(80.0)^{* *}$ & $6(33.3)$ & 0.004 & $12(63.2)$ & $9(50.0)$ & 0.419 \\
\hline Minnesota questionnaire & $1200.0(1694.2)$ & $1863.3(2415.5)$ & 0.330 & $638.3(834.4)$ & $788.4(1052.4)$ & 0.633 \\
\hline
\end{tabular}

${ }^{* *} \mathrm{p}<0.01$; M(SD): mean (standard deviation); $\mathrm{n}(\%)$ : number of individuals (percentage); MCl: mild cognitive impairment; AD: Alzheimer's disease; kg/m²: kilograms per meter squared.

Over the 6-month follow-up, the time spent on both mobility tests was significant worse in fallers compared to non-fallers in the MCI Group. Moreover, the number of steps in the 10MWT was higher in fallers $(\mathrm{p}<0.05)$. In the $\mathrm{AD}$ Group, although there were no significant differences in TUG performance between fallers and non-fallers, the fallers were faster than non-fallers and the cadence was higher in fallers during the 10MWT performance (Table 2).

Table 3 shows the TUG and 10MWT variables that better discriminated fallers and non-fallers in each group. In the MCI Group, the best variable for discriminating fallers was the time spent on the 10MWT, with a cutoff point greater or equal than 10.69 associated with the highest sensibility (80\%) and accuracy (76.3\%). A cut-off point of 13.78 in TUG performance had a $65 \%$ sensibility, $72.2 \%$ specificity and $68.4 \%$ accuracy to predict falls. In the $\mathrm{AD}$ Group, the best variable for discriminating fallers was the cadence of the 10MWT, with a cut-off point $\geq 101.39$ steps/minute associated with the highest specificity (88.9\%) and accuracy (81.1\%). A cut-off point of 17.56 seconds in TUG performance had a $78.9 \%$ sensibility, $61.1 \%$ specificity and $70.2 \%$ accuracy to predict falls.

Table 2. TUG and 10-meter walk tests performances between fallers and non-fallers identified over the 6-month follow-up

\begin{tabular}{|c|c|c|c|c|c|c|}
\hline \multirow[b]{2}{*}{ Variable, M (SD) } & \multicolumn{2}{|c|}{$\mathrm{MCl}$ Group } & \multicolumn{4}{|c|}{ AD Group } \\
\hline & $\begin{array}{l}\text { Fallers } \\
(n=20)\end{array}$ & Non-fallers $(n=18)$ & P-value & $\begin{array}{l}\text { Fallers } \\
(n=19)\end{array}$ & Non-fallers $(n=18)$ & P-value \\
\hline \multicolumn{7}{|l|}{ TUG } \\
\hline Time (seconds) & $16.0(5.5)^{*}$ & $12.5(2.2)$ & 0.018 & $15.0(4.5)$ & $18.2(5.1)$ & 0.057 \\
\hline Number of steps & $20.3(6.1)$ & $17.1(3.5)$ & 0.059 & $18.5(4.9)$ & $21.2(6.5)$ & 0.175 \\
\hline $\begin{array}{l}\text { Cadence (steps/ } \\
\text { min) }\end{array}$ & $77.2(8.5)$ & $81.9(10.1)$ & 0.131 & $74.8(9.1)$ & $69.6(8.0)$ & 0.076 \\
\hline \multicolumn{7}{|l|}{ 10MWT } \\
\hline Time (seconds) & $13.6(4.7)^{* *}$ & $10.2(1.7)$ & 0.007 & $11.2(3.1)^{*}$ & $13.6(2.9)$ & 0.021 \\
\hline Number of steps & $22.3(6.6)^{*}$ & $18.5(3.9)$ & 0.045 & $19.3(3.9)$ & $21.7(4.5)$ & 0.095 \\
\hline $\begin{array}{l}\text { Cadence (steps/ } \\
\text { min) }\end{array}$ & $99.9(12.8)$ & $108.6(15.4)$ & 0.065 & $105.1(12.7)^{* *}$ & $95.4(5.5)$ & 0.005 \\
\hline
\end{tabular}

${ }^{*} p<0.05 ;{ }^{* *} p<0.01 ; \mathrm{M}(\mathrm{SD})$ : mean (standard deviation); $\mathrm{n}(\%)$ : number of individuals (percentage); MCl: Mild cognitive impairment; AD: Alzheimer's disease; TUG: timed up and go test; $10 \mathrm{MWT}$ : 10-meter walk test.

Table 3. Cut-off points of TUG and 10-meter Walk tests for older people with $\mathrm{MCl}$ and $\mathrm{AD}$

\begin{tabular}{|c|c|c|c|c|c|c|c|c|c|}
\hline Groups & Variable & $\begin{array}{c}\text { AUC } \\
(95 \% \mathrm{Cl})\end{array}$ & P-value & Cut-off point & Sensibility & Specificity & Accuracy & $\begin{array}{c}\text { Positive } \\
\text { Likelihood ratio }\end{array}$ & $\begin{array}{l}\text { Relative risk } \\
(95 \% \mathrm{Cl})\end{array}$ \\
\hline \multirow{8}{*}{$\begin{array}{l}\mathrm{MCl} \text { : Fallers vs. } \\
\text { non-fallers }\end{array}$} & TUG & & & & & & & & \multirow{5}{*}{$\begin{array}{r}2.06 \\
(1.06-4.00)\end{array}$} \\
\hline & Time & $\begin{array}{r}0.70 \\
(0.53-0.86)\end{array}$ & 0.039 & $\geq 13.78$ & $65.0 \%$ & $72.2 \%$ & $68.4 \%$ & 2.34 & \\
\hline & Steps & - & 0.072 & - & - & - & - & - & \\
\hline & Cadence & - & 0.161 & - & - & - & - & - & \\
\hline & 10MWT & & & & & & & & \\
\hline & Time & $\begin{array}{r}0.77 \\
(0.61-0.93)\end{array}$ & 0.005 & $\geq 10.69$ & $80.0 \%$ & $72.2 \%$ & $76.3 \%$ & 2.88 & $\begin{array}{r}3.24 \\
(1.33-7.88)\end{array}$ \\
\hline & Steps & $\begin{array}{r}0.71 \\
(0.54-0.87)\end{array}$ & 0.029 & $\geq 18.50$ & $70.0 \%$ & $61.1 \%$ & $65.8 \%$ & 1.80 & $\begin{array}{r}1.89 \\
(0.93-3.85)\end{array}$ \\
\hline & Cadence & - & 0.054 & - & - & - & - & - & - \\
\hline
\end{tabular}


Table 3. Continuation

\begin{tabular}{|c|c|c|c|c|c|c|c|c|c|}
\hline Groups & Variable & $\begin{array}{c}\text { AUC } \\
(95 \% \mathrm{Cl})\end{array}$ & P-value & Cut-off point & Sensibility & Specificity & Accuracy & $\begin{array}{c}\text { Positive } \\
\text { Likelihood ratio }\end{array}$ & $\begin{array}{l}\text { Relative risk } \\
(95 \% \mathrm{Cl})\end{array}$ \\
\hline \multirow{8}{*}{$\begin{array}{l}\text { AD: fallers vs. } \\
\text { non-fallers }\end{array}$} & TUG & & & & & & & & \\
\hline & Time & $\begin{array}{r}0,70 \\
(0,53-0,87)\end{array}$ & 0,036 & $\leq 17,56$ & $78,90 \%$ & $61,10 \%$ & $70,20 \%$ & 2,03 & $\begin{array}{r}2,56 \\
(1,05-6,20)\end{array}$ \\
\hline & Steps & - & 0,202 & - & - & - & - & - & - \\
\hline & Cadence & - & 0,06 & - & - & - & - & - & - \\
\hline & 10MWT & & & & & & & & \\
\hline & Time & $\begin{array}{r}0,75 \\
(0,59-0,91)\end{array}$ & 0,009 & $\leq 12,31$ & $78,90 \%$ & $66,70 \%$ & $72,90 \%$ & 2,37 & $\begin{array}{r}2,86 \\
(1,17-6,96)\end{array}$ \\
\hline & Steps & - & 0,098 & - & - & - & - & - & - \\
\hline & Cadence & $\begin{array}{r}0,79 \\
(0,62-0,95)\end{array}$ & 0,003 & $\geq 101,39$ & $73,70 \%$ & $88,90 \%$ & $81,10 \%$ & 6,64 & $\begin{array}{r}3,67 \\
(1,67-8,07)\end{array}$ \\
\hline
\end{tabular}

95\% Cl: 95\% confidence interval; AUC: area under the curve; MCl: mild cognitive impairment; AD: Alzheimer's disease; TUG: timed up and go test; 10MWT: 10-meter walk test; $p>0.05$ (null hypothesis is accepted).

Table 4 shows the cross tabulation of older individuals who fell and who did not fall during a 6-month follow-up classified based on the TUG and the 10MWT cut-off points. In the MCI Group, considering 10.69 seconds as the best predictive value of the 10MWT, the positive predictive value was $76.19 \%$ and the negative predictive value was $76.47 \%$. Regarding the AD Group, considering 101.39 steps/minute as the best predictive value of the 10MWT, the positive predictive value was $87.50 \%$ and the negative predictive value was $76.19 \%$.

Table 4. Cross tabulation of fall risk assessment results using the timed up and go test and 10-meter walk test

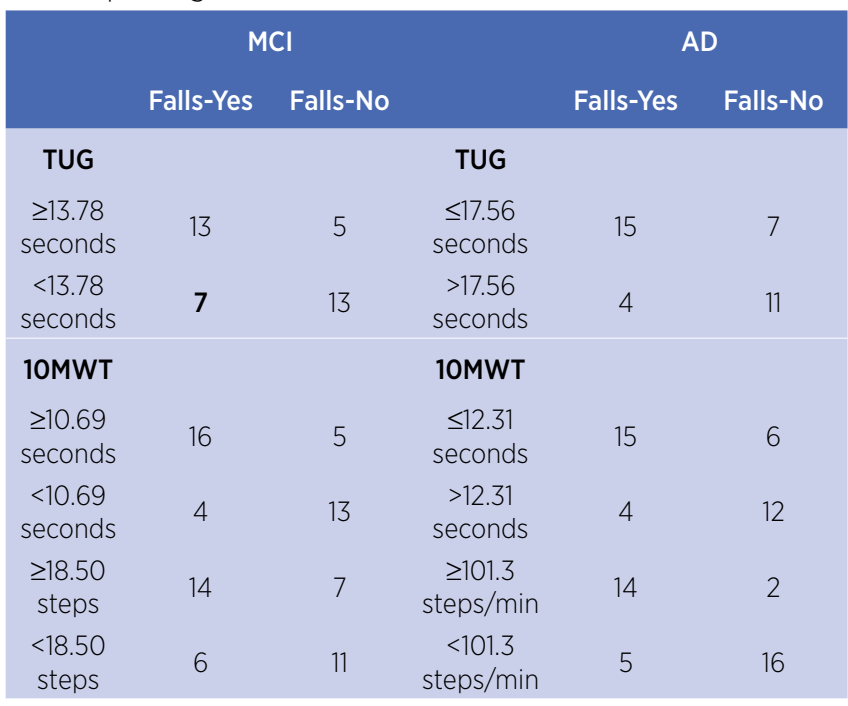

MCI: mild cognitive impairment; AD: Alzheimer disease; TUG: timed up and go; 10MWT: 10-meter walk test.

\section{DISCUSSION}

This study investigated which of the two commonly used functional mobility tools (TUG and 10MWT) best discriminated the risk of falls in older people with
MCI and mild AD. The main findings of this study indicated that the time spent on the 10MWT was the most effective variable to differentiate fallers and nonfallers in the MCI Group, while the variable that best discriminated fallers and non-fallers in the AD Group was the cadence of the 10MWT.

In this study, fallers showed higher prevalence of previous falls compared to non-fallers in the MCI Group, which corroborates the findings of Taylor et al. ${ }^{18}$ Moreover, fallers with MCI were slower in both tests than non-fallers and they spent more steps in the 10MWT. In agreement with our results, the authors found that fallers with cognitive impairment were slower and had a shorter length step in the 4.6-meter walk test, which might be associated with number of steps, compared to non-fallers ${ }^{18}$. Mobility and balance disturbances in older people ${ }^{19,20}$, particularly with $\mathrm{MCI}^{21,22}$, could be associated with changes in the prefrontal cortex, which is responsible for executive functions and increases the risk for occurrence of falls. Thus, mobility tests could be used as assessment tools for those who either manifest or are at risk for developing cognitive impairment ${ }^{23}$.

In the $\mathrm{AD}$ Group, no differences at baseline were found between fallers and non-fallers. There are some divergences in the definition of fallers and non-fallers among studies ${ }^{10,18,21}$, which impairs the comparison with our findings. In this study, a faller was considered as a person who fell at least once during the follow-up, and both subgroups showed a high prevalence of previous falls. Also, fallers showed lower time and higher cadence in the 10MWT performance than non-fallers. A higher grade of periventricular white matter lesions was identified among fallers compared to non-fallers in older people with mild to moderate $\mathrm{AD}$, which may be related to cognition and postural balance ${ }^{24}$. Despite the high prevalence of falls, 
older people with mild AD show less fear of falling than people with preserved cognition and $\mathrm{MCI}^{3}$. Therefore, a lack of perception of their own abilities and consciousness of their alterations may have influenced the 10MWT performance of fallers with $\mathrm{AD}$, which might be related to less caution and protection strategies than non-fallers. Furthermore, a lower time in walk tests does not always mean a better mobility performance. As mechanisms related to falls may differ depending on the phase of $\mathrm{AD}$, more studies are needed to compare mobility performance between fallers and non-fallers with mild AD.

In this study, the 10MWT was better than the TUG test in discriminating fallers and non-fallers with $\mathrm{MCI}$ and mild AD. Taylor et al..$^{5}$ verified that fallers with cognitive impairment showed slower gait speed in simple gait than complex tasks conditions compared to nonfallers ${ }^{5}$. Thus, the addition of a complex task provided no added benefit in discriminating fallers. In this context, our results may be explained since TUG is a more challenging test and it is composed by more subtasks (sit-to-stand, walking forward, turn, walking back and turn-to-sit) ${ }^{25}$. Thus, the 10MWT was the best test for discriminating fallers because the TUG test presented a higher degree of difficulty for both groups compared to 10MWT.

Additionally, the time spent on 10MWT was the best variable in distinguishing fallers with $\mathrm{MCI}$, while the cadence of 10MWT better discriminated fallers with AD. Taylor et al. ${ }^{5}$ also concluded that the time spent on a walk test was able to discriminate fallers and non-fallers with cognitive impairment. However, these authors studied a heterogeneous group, without separating the different degrees of cognitive impairment. Regarding the AD Group, our results are in agreement with several authors who verified that cadence predicted the risk of falls in people with $\mathrm{AD}^{11,26,27}$. Alterations in cadence were related to frontal cognitive functions, particularly the executive function ${ }^{11}$. According to a systematic review ${ }^{27}$, memory and executive attention are associated with cadence and rhythm ${ }^{28}$, and these components are altered in people with $\mathrm{AD}^{29}$. Thus, the cadence is an important and a simple clinical measure to predicted falls in AD.

Although this study could determine which of the two functional mobility tools best discriminated risk of falls in a specific sample of older community people with MCI and mild $\mathrm{AD}$, the authors recognize some limitations. The non-random sampling makes the generalization of our results unfeasible to Brazilian older adults. On the other hand, the authors worried about accurate falls data and distinguishing fallers and non-fallers in specific degrees of cognitive impairment. Knowing that the type of MCI and other classifications of fallers (sporadic and recurrent faller) might influence mobility performances and validation of the mobility tools studied for this population is scarce, new studies considering the above factors are needed to confirm our results.

In conclusion, the time and the cadence of 10MWT were the most accurate variables for screening the risk of falls among MCI Group and mild AD Group, respectively. The 10.69 second and the 101.39 steps/minute cut-off points seem to be the better predictive values for Brazilian older adults with MCI and mild AD, respectively. Besides, the 10MWT is a functional, simple and easy test, and, therefore, should be widely used in clinical practice.

\section{ACKNOWLEDGMENTS}

This study was supported by the Coordination for the Improvement of Higher Education Personnel (Capes). The funders had no role in study design, data collection and analysis, decision to publish, or preparation of manuscript.

\section{REFERENCES}

1. Montero-Odasso M, Muir SW, Speechley M. Dual-task complexity affects gait in people with mild cognitive impairment: the interplay between gait variability, dual tasking, and risk of falls. Arch Phys Med Rehabil. 2012;93(2):293-9. doi: 10.1016/j.apmr.2011.08.026

2. Chen S-F, Huang S-F, Lu L-T, Wang M-C, Liao J-Y, Guo J-L. Patterns of perspectives on fall-prevention beliefs by community-dwelling older adults: a $Q$ method investigation. BMC Geriatr. 2016;16:132. doi: 10.1186/s12877-016-0307-1

3. Borges SM, Radanovic M, Forlenza OV. Fear of falling and falls in older adults with mild cognitive impairment and Alzheimer's disease. Neuropsychol Dev Cogn B Aging Neuropsychol Cogn. 2015;22(3):312-321. doi: 10.1080/13825585.2014.933770

4. Castrillo A, Olmos LMG, Rodríguez F, Duarte J. Gait disorder in a cohort of patients with mild and moderate alzheimer's disease. Am J Alzheimers Dis Other Demen. 2016;31(3):257-62. doi: 10.1177/1533317515603113

5. Taylor ME, Delbaere K, Mikolaizak AS, Lord SR, Close JC. Gait parameter risk factors for falls under simple and dual task conditions in cognitively impaired older people. Gait Posture. 2013;37(1):126-30. doi: 10.1016/j.gaitpost.2012.06.024

6. American Geriatrics Society and British Geriatrics Society. Summary of the updated American geriatrics society/british geriatrics society clinical practice guideline for prevention of falls in older persons. J Am Geriatr Soc. 2011;59(1):148-57. doi: 10.1111/j.1532-5415.2010.03234.x 
7. Garcia-Pinillos F, Cozar-Barba M, Munoz-Jimenez M, Soto-Hermoso V, Latorre-Roman P. Gait speed in older people: an easy test for detecting cognitive impairment, functional independence, and health state. Psychogeriatrics. 2016;16(3):165-171. doi: 10.1111/psyg.12133

8. Tiedemann A, Shimada H, Sherrington C, Murray S, Lord S. The comparative ability of eight functional mobility tests for predicting falls in community-dwelling older people. Age Ageing. 2008:37(4):430-5. doi: 10.1093/ageing/afn100

9. Alexandre TS, Meira DM, Rico NC, Mizuta SK. Accuracy of timed up and go test for screening risk of falls among communitydwelling elderly. Rev Bras Fisioter. 16(5):381-8. doi: 10.1590/ S1413-35552012005000041

10. Allan LM, Ballard CG, Rowan EN, Kenny RA. Incidence and prediction of falls in dementia: a prospective study in older people. PLoS ONE. 2009;4(5):e5521. doi: 10.1371/journal.pone.0005521

11. Coelho FG, Stella F, Andrade LP, Barbieri FA, Santos-Galduróz RF, Gobbi S, et al. Gait and risk of falls associated with frontal cognitive functions at different stages of Alzheimer's disease. Neuropsychol Dev Cogn B Aging Neuropsychol Cogn. 2012;19(5):644-56. doi: 10.1080/13825585.2012.661398

12. Ansai JH, Andrade LP, Rossi PG, Takahashi ACM, Vale FAC, Rebelatto JR. Gait, dual task and history of falls in elderly with preserved cognition, mild cognitive impairment, and mild Alzheimer's disease. Braz J Phys Ther. 2017;21(2):144-51. doi: 10.1016/j.bjpt.2017.03.010

13. Lustosa LP, Silva JP, Coelho FM, Pereira DS, Parentoni AN, Pereira LSM. Efeito de um programa de resistência muscular na capacidade funcional e na força muscular dos extensores do joelho em idosas pré-frágeis da comunidade: ensaio clínico aleatorizado do tipo crossover. Rev. Bras Fisioter. 2011;15(4):318-24. doi: 10.1590/S1413-35552011000400010

14. Novaes RD, Miranda AS, Dourado VZ. Usual gait speed assessment in middle-aged and elderly Brazilian subjects. Rev Bras Fisioter. 2011;15(2):117-122. doi: 10.1590/S141335552011000200006

15. Shumway-Cook A, Brauer S, Woollacott M. Predicting the probability for falls in community-dwelling older adults using the Timed Up \& Go Test. Phys Ther. 2000;80(9):896-903.

16. Gibson MJS, Andres RO, Kennedy TE, Coppard LC. The prevention of falls in later life. A report of the Kellogg International Work Group on the Prevention of Falls by the Elderly. Dan Med Bull. 1987;34 (Suppl. 4):1-24.

17. Sackett DL. A primer on the precision and accuracy of the clinical examination. JAMA Netw Open. 1992;267(19):2638-44. doi: 10.1001/jama.1992.03480190080037
18. Taylor ME, Ketels MM, Delbaere K, Lord SR, Mikolaizak AS, Close JCT. Gait impairment and falls in cognitively impaired older adults: an explanatory model of sensorimotor and neuropsychological mediators. Age Ageing. 2012;41(5):665-9. doi: 10.1093/ageing/afs057

19. Starr JM, Leaper SA, Murray AD, Lemmon HA, Staff RT, Deary IJ, et al. Brain white matter lesions detected by magnetic resonance [correction of resosnance] imaging are associated with balance and gait speed. J Neurol Neurosurg Psychiatry. 2003;74(1):94-8. doi: 10.1136/jnnp.74.1.94

20. Cavanaugh JC, Blanchard-Fields F. Adult development and aging. 7th ed. Belmont: Wadsworth; 2011.

21. Allali G, Annweiler C, Blumen HM, Callisaya ML, De Cock Am, Kressig RW, et al. Gait phenotype from mild cognitive impairment to moderate dementia: results from the GOOD initiative. Eur J Neurol. 2016;23(3):527-41. doi: 10.1111/ene.12882

22. Blackwood J, Shubert T, Forgarty K, Chase C. Relationships between performance on assessments of executive function and fall risk screening measures in community-dwelling older adults. J Geriatr Phys Ther. 2016;39(2):89-96. doi: 10.1519/ JPT.0000000000000056

23. Pedersen MM, Holt NE, Grande L, et al. Mild cognitive impairment status and mobility performance: an analysis from the Boston RISE study. J Gerontol A Biol Sci Med Sci. 2014;69(12):1511-8. doi: 10.1093/gerona/glu063

24. Horikawa E, Matsui T, Arai H, Seki T, Iwasaki K, Sasaki H. Risk of falls in Alzheimer's disease: a prospective study. Intern Med. 2005;44(7):717-21. doi: 10.2169/internalmedicine.44.717

25. Herman T, Giladi N, Hausdorff JM. Properties of the 'timed up and go' test: more than meets the eye. Gerontology. 2011;57(3):203-10. doi: 10.1159/000314963

26. Camicioli R, Bouchard T, Licis L. Dual-tasks and walking fast: relationship to extra-pyramidal signs in advanced Alzheimer disease. J Neurol Sci. 2006;248(1-2):205-9. doi: 10.1016/ j.jns.2006.05.013

27. Morris R, Lord S, Bunce J, Burn D, Rochester L. Gait and cognition: mapping the global and discrete relationships in ageing and neurodegenerative disease. Neurosci Biobehav Rev. 2016;64:326-45. doi: 10.1016/j.neubiorev.2016.02.012

28. Holtzer R, Wang C, Verghese J. The relationship between attention and gait in aging: facts and fallacies. Motor Control. 2012;16(1):64-80.

29. Yogev-Seligmann G, Hausdorff JM, Giladi N. The role of executive function and attention in gait. Mov Disord. 2008;23(3):329-42. doi: $10.1002 /$ mds. 21720 